\title{
Synthesis, Characterization and Biological Studies of Homobimetallic Schiff Base Cu(II) and Ni(II) Complexes
}

\author{
D. SAKTHILATHA and R. RAJAVEL* \\ Department of Chemistry, Periyar University, Salem-636 011, Tamilnadu, India \\ rajavelpu@gmail.com
}

Received 2 December 2012 / Accepted 19 December 2012

\begin{abstract}
New bidentate ligands $N^{l}, N^{4}$-bis(2-amino-5-nitrobenzylidene)benzene-1,4-diamine, $\mathrm{L}^{1}$ and $N^{4}, N^{4^{4}}$-bis(2-amino-5-nitrobenzylidene)biphenyl-4,4'-diamine, $\mathrm{L}^{2}$ have been synthesized. The ligand $\mathrm{L}^{1}$ and $\mathrm{L}^{2}$ were treated with $\mathrm{Cu}\left(\mathrm{OCOCH}_{3}\right)_{2} \cdot \mathrm{H}_{2} \mathrm{O}$ and $\mathrm{Ni}\left(\mathrm{OCOCH}_{3}\right)_{2} \cdot 4 \mathrm{H}_{2} \mathrm{O}$ to afford the new homobimetallic complexes $\left[\mathrm{CuL}^{1}\right]_{2} \cdot 4(\mathrm{OAc})(\mathbf{1}),\left[\mathrm{NiL}^{1}\right]_{2} \cdot 4(\mathrm{OAc})(\mathbf{2}),\left[\mathrm{CuL}^{2}\right]_{2} \cdot 4(\mathrm{OAc})(3)$ and $\left[\mathrm{NiL}^{2}\right]_{2} \cdot 4(\mathrm{OAc})(\mathbf{4})$ respectively. The four new homobimetallic complexes have been characterized by spectral techniques like elemental analysis, NMR, IR, UV Visible absorption, magnetic measurements, thermal, EPR, electrochemical studies and molar conductance. IR spectral data shows that the ligands are bidentate and the binding sites are azomethine nitrogen and free primary amine groups. Molar conductance measurements show that the complexes are electrolytes. EPR values and electronic spectral data suggest that it possesses square planar geometry. The Schiff base ligands and metal complexes were evaluated for antimicrobial activity against gram positive bacteria and gram negative bacteria. The ligands and its metal complexes were found to be biologically active. All the complexes show higher antimicrobial activity than the ligand and streptomycin.
\end{abstract}

Keywords: 2-Amino-5-nitrobenzaldehyde, Schiff base ligands, Homobimetallic, Electrochemical, Antibacterial activity.

\section{Introduction}

Transition metal ions with Schiff-bases have been extended enormously and embraced wide and diversified subjects comprising vast areas of organometallic compounds ${ }^{1}$ and various aspects of biocoordination chemistry ${ }^{2}$. Schiff base ligands with donors $\mathrm{N}, \mathrm{O}, \mathrm{S}$ etc., have structural similarities with natural biological systems and imports and rasemination reaction in biological systems due to presence of imine $(-\mathrm{N}=\mathrm{CH}-)_{\text {group }}^{3}$. Schiff bases are important intermediate for the synthesis of bioactive compounds ${ }^{4-6}$. Schiff bases metal complexes have applications in the area of material science to biological sciences ${ }^{7-9}$.

Schiff-base ligands that are able to form binuclear transition metal complexes are useful to study the relation between structures and magnetic exchange interactions ${ }^{10}$ and, to mimic bimetallic biosites in various proteins and enzymes ${ }^{11}$. Metal complexes play an important role in developing the coordination chemistry related to catalysis, enzymatic reactions, magnetism and bioinorganic modeling studies ${ }^{12-13}$. Binuclear metal complexes have been 
used as a versatile building unit for constructing various supramolecular assemblies ${ }^{14-16}$. Synthetic binuclear copper(II) complexes provide models for metalloprotein active sites and lend insight towards the design of new catalysts. Copper complexes have medical uses in the treatment of numerous diseases including cancer ${ }^{17-18}$. Synthetic binuclear Ni(II) complexes are imperative to understand the mutual influences of the two metal on the electronic, magnetic and catalytic properties of such bimetallic cores ${ }^{19-23}$. Bimetallic Schiff base metal complexes have better biologically activity than the mononuclear Schiff base metal complexes, due to two biocompatible metal ions in the complexes. In this regard, there is much current interest in designing dinucleating ligands and their transition metal complexes.

In this paper we have reported on the synthesis, characterization and antimicrobial activity of homobinuclear copper(II) and nickel(II) complexes containing binucleating Schiff base derived from 2-amino-5-nitrobenzaldehyde with $p$-phenylenediamine $\left(\mathrm{L}^{1}\right)$ and benzidine $\left(\mathrm{L}^{2}\right)$ with a special impetus on ligand structure investigations.

\section{Experimental}

$p$-Phenylenediamine, 2-nitobenzaldehyde, $\left(\mathrm{CH}_{3} \mathrm{COO}\right)_{2} \mathrm{Cu} \cdot \mathrm{H}_{2} \mathrm{O}$ and $\left(\mathrm{CH}_{3} \mathrm{COO}\right)_{2} \mathrm{Ni} .4 \mathrm{H}_{2} \mathrm{O}$ were purchased from Loba cheime. Benzidine was purchased from Merck. All chemicals and solvents were of analytical grade and used as received. Solvents were purified using standard methods ${ }^{24}$. 2-Amino-5-nitrobenzaldehyde was prepared by literature procedure ${ }^{25}$.

\section{Instruments}

Melting points of all newly prepared compounds were determined in open capillaries and are uncorrected. Micro analysis carried out on a Perkin - Elmer $2400 \mathrm{CHN}$ elemental analyser. The metal content of the complexes were determined according to the literature methods ${ }^{26}$. The molar conductance of the binuclear Schiff base complexes was determined on a Systronic direct reading conductivity meter. The Fourier transform infrared spectra of the complexes were recorded on a perkin Elmer spectrum RXI. FTIR in the range of $4000-400 \mathrm{~cm}^{-1}$ as solid $\mathrm{KBr}$ pellets. Electronic spectra in the $200-800 \mathrm{~nm}$ range were obtained in DMF on a SHIMADZU UV 160A instrument using $1 \mathrm{~mL}$ quartz cell. The ${ }^{1} \mathrm{H}$ NMR \& ${ }^{13} \mathrm{C}$ NMR spectra of intermediates and ligands were recorded in $\mathrm{CDCl}_{3}$ and DMSO- $d_{6}$ on a BRUKER $500 \mathrm{MHz}$ spectrometer at room temperature using TMS as an internal reference. Electrochemical measurements were performed with a digital $\mathrm{CHI760C}$ recorder. The $\mathrm{X}$-band ESR spectra of $\mathrm{Cu}$ (II) complexes were recorded at room temperature on a JEOLFA200 ESR spectrophotometer with diphenylpicrylhydrazine (DPPH) as the reference. Variable temperature magnetic studies were performed on a PAR model 155 vibrating sample magnetometer in the temperature range 77-300 K. The thermal analysis studies of the complexes were performed on a Perkin-Elmer Pyris Diamond DTA/TG Thermal system under nitrogen atmosphere at a heating rate of $10{ }^{\circ} \mathrm{C} / \mathrm{min}$. The antimicrobial activity was evaluated using the disc diffusion methods.

\section{Synthesis of precursor 2-amino-5-nitrobenzaldehyde}

The precursor 2-amino-5-nitrobenzaldehyde (1a-4a) was prepared with modifications in the literature $^{25}$ (Scheme 1). 2-Aminobenzaldehyde (1a): Molecular formula: $\mathrm{C}_{7} \mathrm{H}_{7} \mathrm{NO}$, Formula weight: 121.14 , white color, Yield: $91 \%$, M.p: $36^{\circ} \mathrm{C}$. Elemental analysis (\%), Calculated: C, 69.41; H, 5.82; N, 11.56. Found: C, 69.02; H, 5.75; N, 11.63. IR ( KBr discs, $\left.\mathrm{cm}^{-1}\right): 3395$ $v\left(\mathrm{NH}_{2}\right) ; 1705 v(-\mathrm{CHO}) ; 1560 v(\mathrm{C}=\mathrm{C})$. 


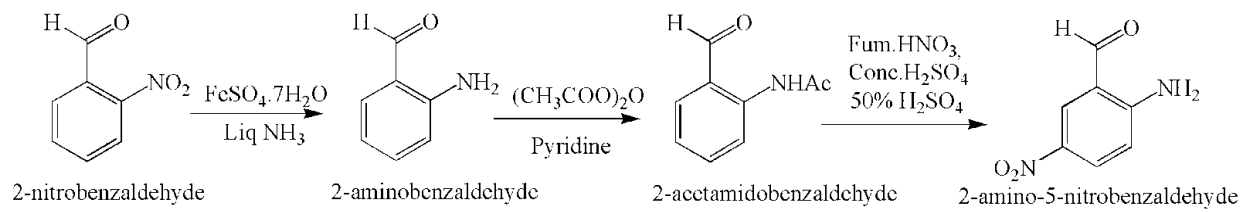

Scheme 1. Synthesis of the precursor $(\mathbf{1 a}-\mathbf{4 a})$

2-Acetamidobenzaldehyde (2a)

Molecular formula: $\mathrm{C}_{9} \mathrm{H}_{6} \mathrm{~N}_{2} \mathrm{O}_{3}$, Formula weight: 163.17, white color, Yield: 65\%, M.p: $69{ }^{\circ} \mathrm{C}$. Elemental analysis (\%), Calculated: C, 66.25; H, 5.56; N, 8.58. Found: C, 66.12; H, 5.65; N, 8.25. $\mathrm{H}^{1} \mathrm{NMR}\left(\mathrm{CDCl}_{3}, \delta \mathrm{ppm}\right)$ (Figure 1a \& 1b): $2.2\left(\mathrm{~s}, 3 \mathrm{H}, \mathrm{CH}_{3}\right), 7.55-7.63(\mathrm{~m}, 4 \mathrm{H}, \mathrm{Ar}-\mathrm{H})$, 8.68 (s. $1 \mathrm{H}, \mathrm{NH}), 9.87$ (s, 1H, Ar-CHO); $\mathrm{C}^{13} \mathrm{NMR}\left(\mathrm{CDCl}_{3}, \delta \mathrm{ppm}\right): 25.3$ (s, 1C, $\left.\mathrm{CH}_{3}\right), 119-140$ (m, 6C, Aromatic carbons), 169 (s, 1C, Carbonyl (-CO-)), 195 (s, 1C, Ar-CHO). M.p. $=69^{\circ} \mathrm{C}, \mathrm{IR}$ $\left(\mathrm{KBr}\right.$ discs, $\left.\mathrm{cm}^{-1}\right): 3340 v(\mathrm{NH}) ; 1705 v(-\mathrm{CHO}) ; 1566 v(\mathrm{C}=\mathrm{C}) ; 2953 v\left(-\mathrm{CH}_{3}\right)$.
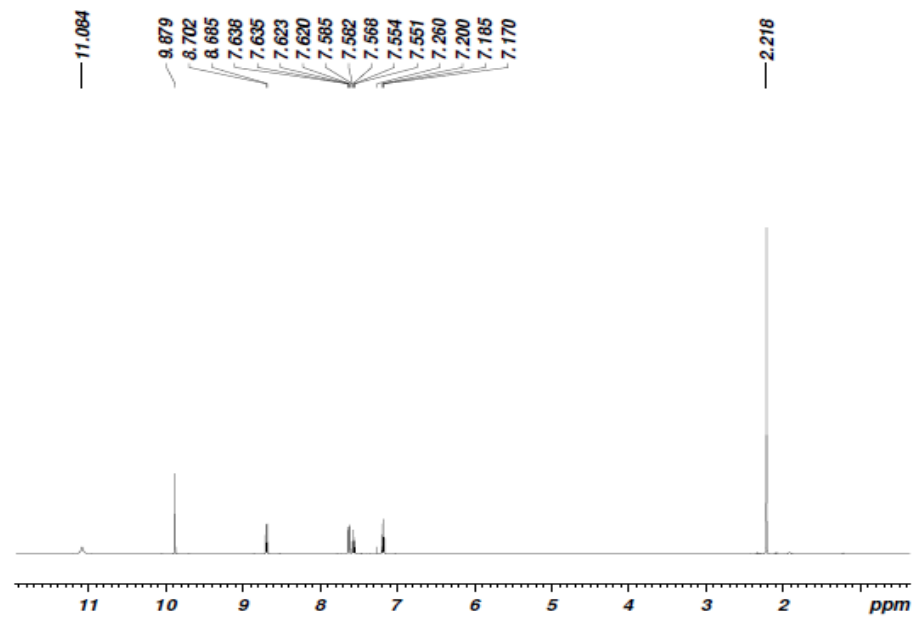

Figure 1a. $\mathrm{H}^{1}$ NMR Spectra of 2-acetamidobenzaldehyde (2a)

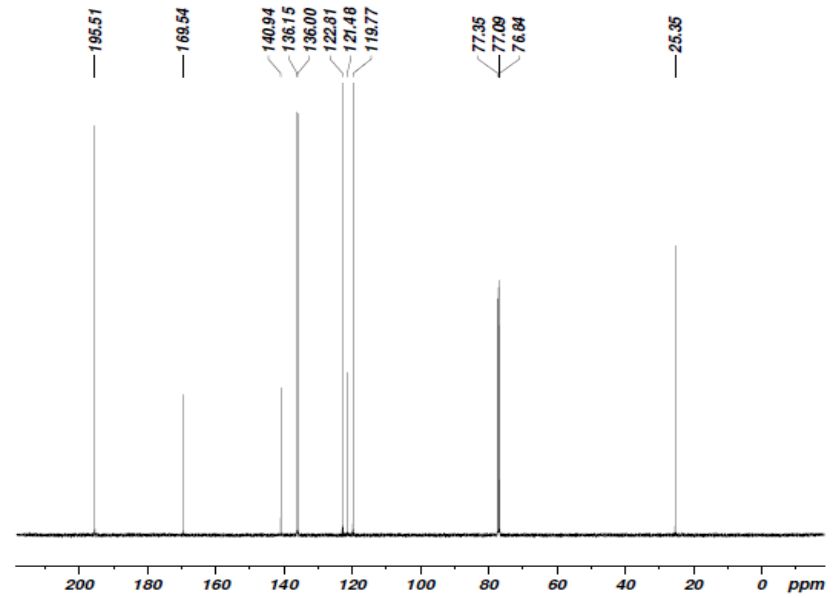

Figure 1b. $C^{13}$ NMR Spectra of 2-acetamidobenzaldehyde (2a) 


\section{2-Acetamido-5-nitrobenzaldehyde (3a)}

Molecular formula: $\mathrm{C}_{9} \mathrm{H}_{8} \mathrm{~N}_{2} \mathrm{O}_{4}$, Formula weight: 208.17, Light yellow color, Yield: 85\%, M.p: $160{ }^{\circ} \mathrm{C}$. Elemental analysis (\%), Calculated: C, 51.93; H, 3.87; N, 13.46. Found: C, 52.05; H, 3.76; N, 13.37. $\mathrm{H}^{1} \mathrm{NMR}\left(\mathrm{CDCl}_{3}, \delta \mathrm{ppm}\right)$ (Figure 2a \& 2b): $2.3\left(\mathrm{~s}, 3 \mathrm{H}_{1} \mathrm{CH}_{3}\right), 8.43-8.60(\mathrm{~m}, 4 \mathrm{H}$, $\mathrm{Ar}-\mathrm{H}), 8.9$ (s. $1 \mathrm{H}, \mathrm{NH}), 10.0(\mathrm{~s}, 1 \mathrm{H}, \mathrm{Ar}-\mathrm{CHO}) ; \mathrm{C}^{13} \mathrm{NMR}\left(\mathrm{CDCl}_{3}, \delta \mathrm{ppm}\right): 25.5\left(\mathrm{~s}, 1 \mathrm{C}, \mathrm{CH}_{3}\right)$, 120-145 (m, 6C, Aromatic carbons), 169 (s, 1C, Carbonyl (-CO-)), 193 (s, 1C, Ar-CHO). M.p. $=160{ }^{\circ} \mathrm{C}, \mathrm{IR}\left(\mathrm{KBr} \operatorname{discs}, \mathrm{cm}^{-1}\right): 3346 v(\mathrm{NH}) ; 1704 v(-\mathrm{CHO}) ; 1575 v(\mathrm{C}=\mathrm{C}) ; 2955 v\left(-\mathrm{CH}_{3}\right)$.

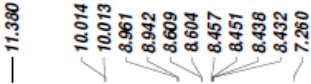

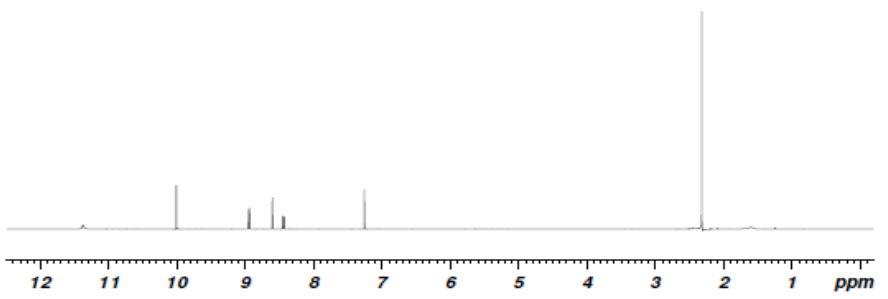

Figure 2a. $\mathrm{H}^{1} \mathrm{NMR}$ Spectra of 2-acetamido-5-nitrobenzaldehyde (3a)

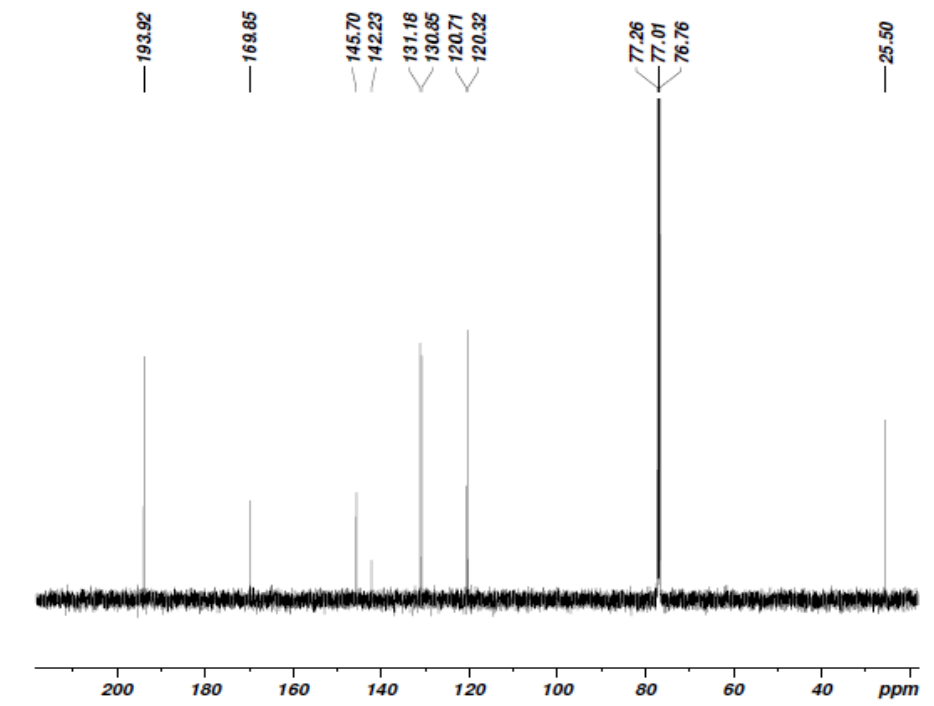

$$
\text { స్్ㅍ }
$$

Figure 2b. $\mathrm{C}^{13}$ NMR Spectra of 2-acetamido-5-nitrobenzaldehyde (3a)

\section{2-Amino-5-nitrobenzaldehyde (4a)}

Molecular formula: $\mathrm{C}_{7} \mathrm{H}_{6} \mathrm{~N}_{2} \mathrm{O}_{3}$, Formula weight: 166.13, yellow color, Yield: 93\%. M.p.= $200{ }^{\circ} \mathrm{C}$, Elemental analysis (\%), Calculated: C, 50.61; H, 3.64; N, 16.86. Found: C, 50.46; $\mathrm{H}, 3.58 ; \mathrm{N}, 16.74 . \mathrm{IR}\left(\mathrm{KBr}\right.$ discs, $\left.\mathrm{cm}^{-1}\right): 3396 v\left(\mathrm{NH}_{2}\right) ; 1706 v(-\mathrm{CHO}) ; 1577 v(\mathrm{C}=\mathrm{C})$. 


\section{Synthesis of Schiff base ligands}

The Schiff base ligands $N^{l}, N^{4}$-bis(2-amino-5-nitrobenzylidene)benzene-1,4-diamine, $\left(\mathbf{L}^{\mathbf{1}}\right)$ and $N^{4}, N^{4^{\prime}}$-bis(2-amino-5-nitrobenzylidene)biphenyl-4,4'-diamine, $\left(\mathbf{L}^{2}\right)$ were prepared by the literature method ${ }^{27}$. 2-Amino-5-nitrobenzaldehyde $(0.25 \mathrm{~g}, 1.5 \mathrm{mmole})$ was dissolved in a mixture of acetonitrile $(10 \mathrm{~mL})$ and dichloromethane $(10 \mathrm{~mL})$, to with ethanolic / methanolic solution of aromatic diamine $(0.75 \mathrm{mmole})$ like $p$-phenylenediamine, benzidine was added. The solution was refluxed for 8-10 hours and then allowed to stand for 3 days. The solvent was removed under vacuum and upon addition of diethylether, a coloured powder precipitated; this was recovered by filtration washed with diethylether (Scheme 2).

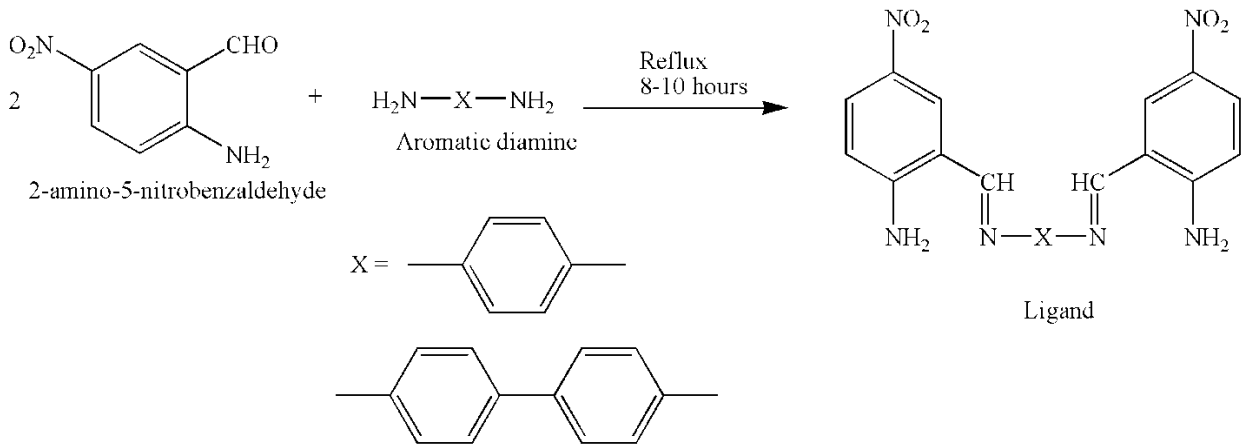

Scheme 2. Synthesis of the Schiff base ligands

\section{Synthesis of Schiff base metal complexes}

Ligands $\left(\mathrm{L}^{1} \& \mathrm{~L}^{2}\right)(0.62 \mathrm{mmole})$ was dissolved in dry tetrahydrofuran $(10 \mathrm{~mL})$ to which $\mathrm{M}(\mathrm{OAc})_{2}(0.62 \mathrm{mmole}, \mathrm{M}=\mathrm{Cu}$ and $\mathrm{Ni})$ in absolute ethanol $(10 \mathrm{~mL})$ was added and the reaction mixture stirred for an hour. The solution was refluxed for 6 hours. The solution was allowed to stand overnight and reduced to half its volume under vaccum, after which a color solid precipitated; this was filtered off, washed with diethylether (10 mL) (Scheme 3).

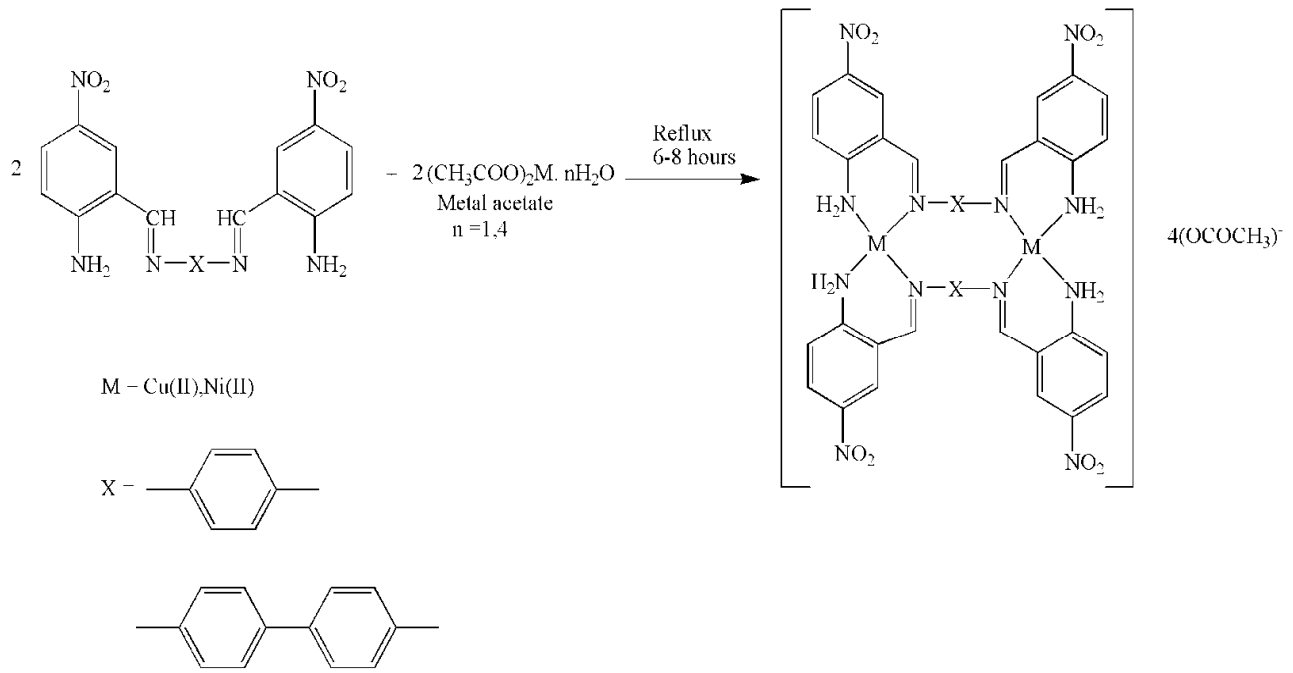

Scheme 3. Synthesis of binuclear Schiff base complexes 


\section{Antibacterial activity}

For the bacterial organisms, both gram positive and gram negative bacteria used. Gram positive and gram negative bacteria can be differentiated in the physical appearance of their cell envelopes. The compounds were screened for their in vitro antibacterial activities. The bacteria was inoculated into nutrient broth and incubated for 24 hours. In the disc diffusion method, the sterile Mueller Hinton Agar for bacterium was separately inoculated with the test microorganisms ${ }^{28}$. The compounds dissolved in DMSO as $50 \mu \mathrm{g} / \mathrm{disc}$ solutions and absorbed on the sterile paper antibiotic disc were placed in wells (6 $\mathrm{mm}$ diameter) cut in the agar media and the plates were incubated at $32{ }^{\circ} \mathrm{C}$ for bacterium $(18-24 \mathrm{~h})$. The resulting inhibition zones on the plates were measured after $48 \mathrm{~h}$. The controlled samples were only absorbed in DMSO.

\section{Results and Discussion}

Condensation reaction of precursor 2-amino-5-nitrobenzaldehyde (1a-4a) with $p$-phenylenediamine / benzidine gave good yield containing azomethine and free primary amine group moieties. All prepared compounds were air stable solids with high melting points, producing intense color in their solutions. The elemental analysis data for the complexes with ligands were in good agreement with the general formula $\mathrm{M}_{2} \mathrm{~L}_{2}$. The high conductance values of chelates support the electrolytic (1:2) nature of metal complexes. Several attempts failed to obtain a single crystal suitable for x-ray crystallography. The active sites of the ligands and their coordination to the metal atoms as well as the structure of the resulting complexes were inferred by spectral and magnetic measurements. The analytical data are reported in Table 1.

Table 1. Elemental analysis data and some physical properties of the ligands and its metal complexes

\begin{tabular}{|c|c|c|c|c|c|c|c|c|}
\hline \multirow[t]{2}{*}{ Compound } & \multirow{2}{*}{$\begin{array}{l}\text { Molecular } \\
\text { formula }\end{array}$} & \multirow[t]{2}{*}{ Color } & \multirow{2}{*}{$\begin{array}{c}\text { Yield } \\
\%\end{array}$} & \multirow{2}{*}{$\begin{array}{l}\text { M.P., } \\
{ }^{\circ} \mathrm{C}\end{array}$} & \multicolumn{4}{|c|}{ Calcd.(Found) \% } \\
\hline & & & & & $\mathrm{C}$ & $\mathrm{H}$ & $\mathrm{N}$ & M \\
\hline $\mathrm{L}^{\mathrm{T}}$ & $\mathrm{C}_{20} \mathrm{H}_{16} \mathrm{~N}_{6} \mathrm{O}_{4}$ & Green & 76 & $>250$ & $\begin{array}{c}59.40 \\
(58.90)\end{array}$ & $\begin{array}{c}3.96 \\
(3.89)\end{array}$ & $\begin{array}{c}20.79 \\
(20.75)\end{array}$ & - \\
\hline $\mathrm{L}^{2}$ & $\mathrm{C}_{26} \mathrm{H}_{20} \mathrm{~N}_{6} \mathrm{O}_{4}$ & Yellow & 80 & $>250$ & $\begin{array}{c}65.00 \\
(64.55)\end{array}$ & $\begin{array}{c}4.16 \\
(4.10)\end{array}$ & $\begin{array}{c}17.50 \\
(17.33)\end{array}$ & - \\
\hline$\left[\mathrm{CuL}^{1}\right]_{2} \cdot 4(\mathrm{OAc})$ & $\mathrm{C}_{48} \mathrm{H}_{44} \mathrm{~N}_{12} \mathrm{O}_{16} \mathrm{Cu}_{2}$ & Brown & 78 & $>250$ & $\begin{array}{c}49.18 \\
(49.12)\end{array}$ & $\begin{array}{c}3.75 \\
(3.69)\end{array}$ & $\begin{array}{c}14.34 \\
(14.29)\end{array}$ & $\begin{array}{c}10.85 \\
(10.14)\end{array}$ \\
\hline$\left[\mathrm{NiL}^{1}\right]_{2} \cdot 4(\mathrm{OAc})$ & $\mathrm{C}_{48} \mathrm{H}_{44} \mathrm{~N}_{12} \mathrm{O}_{16} \mathrm{Ni}_{2}$ & $\begin{array}{l}\text { Yellowish } \\
\text { green }\end{array}$ & 82 & $>250$ & $\begin{array}{c}49.59 \\
(49.45)\end{array}$ & $\begin{array}{c}3.78 \\
(3.50)\end{array}$ & $\begin{array}{c}14.46 \\
(14.10)\end{array}$ & $\begin{array}{c}10.11 \\
(10.02)\end{array}$ \\
\hline$\left[\mathrm{CuL}^{2}\right]_{2} \cdot 4(\mathrm{OAc})$ & $\mathrm{C}_{60} \mathrm{H}_{52} \mathrm{~N}_{12} \mathrm{O}_{16} \mathrm{Cu}_{2}$ & $\begin{array}{l}\text { Brownish } \\
\text { green }\end{array}$ & 75 & $>250$ & $\begin{array}{c}54.41 \\
(54.30)\end{array}$ & $\begin{array}{c}3.93 \\
(3.72)\end{array}$ & $\begin{array}{c}12.69 \\
(12.42)\end{array}$ & $\begin{array}{c}9.60 \\
(9.32)\end{array}$ \\
\hline$\left[\mathrm{NiL}^{2}\right]_{2} \cdot 4(\mathrm{OAc})$ & $\mathrm{C}_{60} \mathrm{H}_{52} \mathrm{~N}_{12} \mathrm{O}_{16} \mathrm{Ni}_{2}$ & brown & 79 & $>250$ & $\begin{array}{r}54.81 \\
(54.75) \\
\end{array}$ & $\begin{array}{r}3.95 \\
(3.82) \\
\end{array}$ & $\begin{array}{r}12.79 \\
(12.59) \\
\end{array}$ & $\begin{array}{c}8.94 \\
(8.55)\end{array}$ \\
\hline
\end{tabular}

In order to identify structure of the ligand, $\mathrm{H}^{1}$ NMR spectra were recorded in DMSO- $d_{6}$ (Figure 3). The spectra showed one signal at chemical shift $3.65 \mathrm{ppm}$ for protons of aromatic primary amine group respectively. The peaks observed in the range 6.6-8.5 ppm are assigned to the protons of aromatic units as multiple peaks. The signal due to the $\mathrm{HC}=\mathrm{N}$ group is observed in the expected range of $8.78 \mathrm{ppm}$, but no signals corresponding to the formyl protons are present. This indicates that the binucleating Schiff base ligand has azomethine group. 


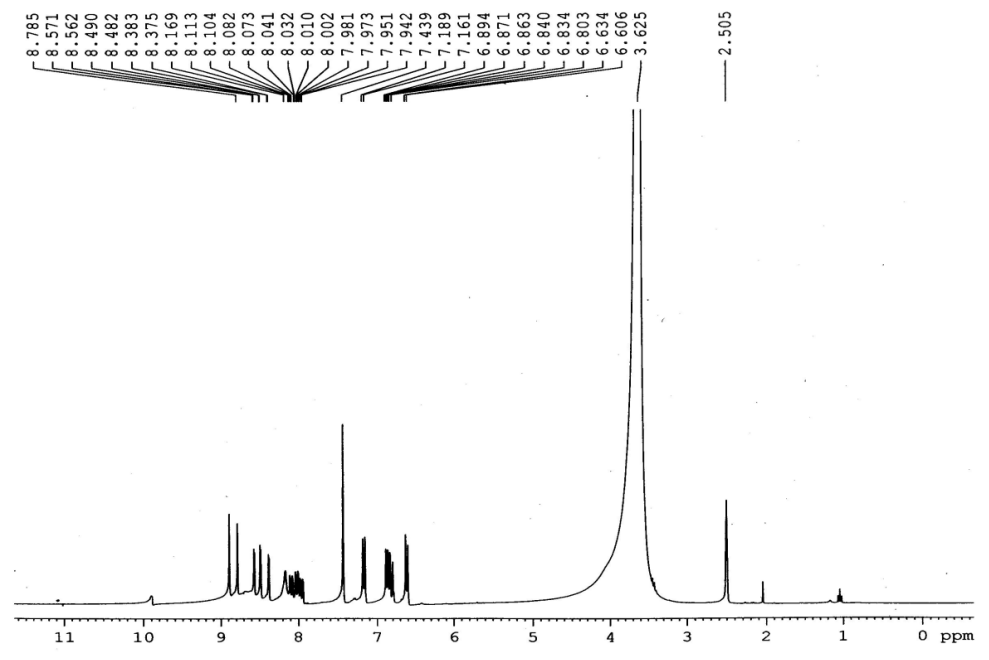

Figure 3. $\mathrm{H}^{1} \mathrm{NMR}$ Spectra of ligand $\mathrm{L}^{1}$

\section{Molar conductivity measurements}

The molar conductivities of the complexes were measured with $1 \mathrm{mmol}$ solution at $30{ }^{\circ} \mathrm{C}$ in DMF. The conductivity data reported for these complexes are given in Table 2 . The product of the cell constant and the measured conductance of a solution give the specific conductivity $\mathrm{k}$. The molar conductance $\left(\Omega^{-1} \mathrm{~cm}^{2} \mathrm{~mol}^{-1}\right)$ is given by the relation, $\Lambda_{\mathrm{m}}=(\mathrm{k} / \mathrm{C}) \mathrm{x}$ 1000 , where $\mathrm{C}(\mathrm{mol} / \mathrm{L})$ is the concentration of the solution. The molar conductance $\left(\Lambda_{\mathrm{m}}\right)$ values of the acetate complexes were carried out in DMF and DMSO medium and the values were found to be in the range $135-165 \Omega^{-1} \mathrm{~cm}^{2} \mathrm{~mol}^{-1}$ and $120-140 \Omega^{-1} \mathrm{~cm}^{2} \mathrm{~mol}^{-1}$ suggesting that the complexes belong to $1: 2$ electrolytes ${ }^{29}$. This conductivity values indicative that the anions may be present outside the coordination sphere. This result was confirmed from the chemical analysis, where $\mathrm{CH}_{3} \mathrm{COO}^{-}$ion gives precipitate by the addition of $\mathrm{FeCl}_{3}$ solution ${ }^{30}$.

Table 2. Molar conductivity $\left(\mathrm{ohm}^{-1} \mathrm{~cm}^{2} \mathrm{~mol}^{-1}\right)$ data of the complexes

\begin{tabular}{cccc}
\hline Complexes & Solvent & $\begin{array}{c}\text { Molar conductance } \\
\Lambda_{\mathrm{m}}\left(\mathrm{ohm}^{-1} \mathrm{~cm}^{2} \mathrm{~mol}^{-1}\right)\end{array}$ & Types of electrolyte \\
\hline$\left[\mathrm{CuL}^{1}\right]_{2} \cdot 4(\mathrm{OAc})$ & DMF & 153 & $1: 2$ \\
& DMSO & 120 & $1: 2$ \\
{$\left[\mathrm{NiL}^{1}\right]_{2} \cdot 4(\mathrm{OAc})$} & DMF & 149 & $1: 2$ \\
& DMSO & 129 & $1: 2$ \\
{$\left[\mathrm{CuL}^{2}\right]_{2} \cdot 4(\mathrm{OAc})$} & DMF & 156 & $1: 2$ \\
& DMSO & 135 & $1: 2$ \\
{$\left[\mathrm{NiL}^{2}\right]_{2} \cdot 4(\mathrm{OAc})$} & DMF & 165 & $1: 2$ \\
& DMSO & 125 & $1: 2$ \\
\hline
\end{tabular}

\section{IR Spectra and mode of bonding}

IR spectra give adequate information to explicate the way of bonding of the binucleating Schiff base ligands to the metal ions. The vibrational frequencies and their tentative assignment for the ligands $\left[\mathrm{L}^{1} \& \mathrm{~L}^{2}\right]$ and their complexes are listed in Table 3 . The IR spectra 
of ligands and complexes show bands in the region $3450-3350 \mathrm{~cm}^{-1}$ indicating the presence of $\mathrm{NH}_{2}$ groups in the complexes. This higher frequency range of $\mathrm{N}-\mathrm{H}$ stretching is due to hydrogen bonding ${ }^{31}$. The IR spectra of precursor (4a) shows a band at $1710 \mathrm{~cm}^{-1}$ due to the presence of a $\mathrm{C}=\mathrm{O}(-\mathrm{CHO})$ group. The free ligands showed a strong band in the region $1610 \mathrm{~cm}^{-1}$ which is characteristic of the azomethine group. The presence of this band confirms the absence of bands due to the aldehyde groups, which have been completely converted into imine groups, as these bands may be assigned to $(\mathrm{C}=\mathrm{N})$ stretching vibrations ${ }^{32-34}$. Coordination of the Schiff bases to the metal through the nitrogen atom is expected to reduce the electron density in the azomethine link and lower the $v(\mathrm{C}=\mathrm{N})$ absorption frequency. In the spectra of all the four homobimetallic complexes, $v(\mathrm{C}=\mathrm{N})$ being shifted to $1602-1609 \mathrm{~cm}^{-1}$, which clearly indicates the coordination of the azomethine nitrogen to the metal atom. The absorption bands in the region $1460-1510 \mathrm{~cm}^{-1}$ may be assigned due to $(\mathrm{C}=\mathrm{C})$ aromatic stretching vibration of the phenyl ring. The ring skeletal vibrations are unaffected by complexation ${ }^{35-36}$.

Table 3. Infrared spectral data $\left(\mathrm{cm}^{-1}\right)$ of the ligand $\left(\mathrm{L}^{1}, \mathrm{~L}^{2}\right)$ and its metal complexes

\begin{tabular}{cccccc}
\hline Compound & $\begin{array}{c}v(\mathrm{~N}-\mathrm{H}), \\
\mathrm{cm}^{-1}\end{array}$ & $\begin{array}{c}v(\mathrm{C}=\mathrm{N}), \\
\mathrm{cm}^{-1}\end{array}$ & $\begin{array}{c}v(\mathrm{C}=\mathrm{C}), \\
\mathrm{cm}^{-1}\end{array}$ & $\begin{array}{c}v(\mathrm{M}-\mathrm{N}), \\
\mathrm{cm}^{-1}\end{array}$ & $\begin{array}{c}v(\mathrm{OAc})_{\text {asym/sym }} \\
\mathrm{cm}^{-1}\end{array}$ \\
\hline $\mathrm{L}^{1}$ & 3444 & 1610 & 1494 & - & - \\
$\mathrm{L}^{2}$ & 3362 & 1610 & 1506 & - & - \\
{$\left[\mathrm{CuL}^{1}\right]_{2} .4(\mathrm{OAc})$} & 3438 & 1608 & 1491 & 517 & $1509 / 1398$ \\
{$\left[\mathrm{NiL}^{1}\right]_{2} .4(\mathrm{OAc})$} & 3432 & 1605 & 1500 & 509 & $1510 / 1400$ \\
{$\left[\mathrm{CuL}^{2}\right]_{2} .4(\mathrm{OAc})$} & 3358 & 1609 & 1466 & 513 & $1506 / 1406$ \\
{$\left[\mathrm{NiL}^{2}\right]_{2} 4(\mathrm{OAc})$} & 3354 & 1602 & 1505 & 505 & $1515 / 1405$ \\
\hline
\end{tabular}

The IR spectra of the copper and nickel acetate complexes, show an absorption band in the region $1504-1517 \mathrm{~cm}^{-1}$ which is assigned to $v\left(\mathrm{COO}^{-}\right)$asymmetric stretching of acetate ion and another in the region $1398-1410 \mathrm{~cm}^{-1}$ and which can be assigned to $v\left(\mathrm{COO}^{-}\right)$symmetric stretching vibration of acetate ion. A difference between $v$ (as-s) is around 106-107 $\mathrm{cm}^{-1}$ which is lower than $144 \mathrm{~cm}$ indicates the presence of an uncoordinated acetate ion with the central metal ion $^{37}$. Molar conductance values also suggest that the acetate ion present in the outside the coordination sphere. The band assignment to vibration $\mathrm{M}-\mathrm{N}$ stretching vibrations in the lower region of the spectra is difficult as the ligand vibration interfere. We assign the bands in the region 505-517v(M-N) stretching vibrations respectively. They were observed as weak bands indicative of the formation of the metal complexes ${ }^{38}$.

\section{Electronic spectral studies}

The electronic spectrum of ligands and complexes were recorded in DMSO. The electronic spectrum provides quick and consistent information about the ligands arrangements in the metal complexes. The absorption regions, assignment and the proposed geometry of the complexes are given in Table 4 . The bands appearing at the lower energy side are attributable to $n \rightarrow \pi^{*}$ transitions connected with the azomethine chromophores. The bands at higher energy arise from $\pi \rightarrow \pi^{*}$ transition within the phenyl rings ${ }^{39}$. The absorption bands of the complexes are shifted to longer wavelength region compared to those of the ligand ${ }^{40}$. The moderative intensive band observed in the region of $24390-25640 \mathrm{~cm}^{-1}$ is attributted to the LMCT transitions respectively. This shift may be attributed to the donation of the lone pairs of electron on the nitrogen atoms of the Schiff base to the metal ions $(\mathrm{N} \rightarrow \mathrm{M})$. 
Table 4. Electronic spectral data $\left(\mathrm{cm}^{-1}\right)$ of ligand and metal complexes

\begin{tabular}{|c|c|c|c|c|c|c|}
\hline Compound & $\begin{array}{l}\mathrm{n} \rightarrow \pi^{*} \\
\mathrm{~cm}^{-1}\end{array}$ & $\begin{array}{l}\pi \rightarrow \pi^{*}, \\
\mathrm{~cm}^{-1}\end{array}$ & $\begin{array}{l}\mathrm{LMCT}, \\
\mathrm{cm}^{-1}\end{array}$ & $\begin{array}{l}\text { d-d transition, } \\
\mathrm{cm}^{-1}\end{array}$ & $\begin{array}{c}\text { Band } \\
\text { assignment }\end{array}$ & Geometry \\
\hline $\mathrm{L}^{1}$ & 33764 & 30581 & - & - & - & - \\
\hline $\mathrm{L}^{2}$ & 33496 & 30303 & - & - & - & - \\
\hline$\left[\mathrm{CuL}^{1}\right]_{2} \cdot 4(\mathrm{OAc})$ & 34232 & 29761 & 24459 & $\begin{array}{l}12900 \\
16789 \\
22653\end{array}$ & $\begin{array}{l}{ }^{2} \mathrm{~B}_{1 \mathrm{~g}} \rightarrow{ }^{2} \mathrm{~A}_{1 \mathrm{~g}} \\
{ }^{2} \mathrm{~B}_{1 \mathrm{~g}} \rightarrow{ }^{2} \mathrm{~B}_{2 \mathrm{~g}} \\
{ }^{2} \mathrm{~B}_{1 \mathrm{~g}} \rightarrow{ }^{2} \mathrm{E}_{\mathrm{g}}\end{array}$ & $\begin{array}{l}\text { Square } \\
\text { planar }\end{array}$ \\
\hline$\left[\mathrm{NiL}^{1}\right]_{2} \cdot 4(\mathrm{OAc})$ & 33129 & 30864 & 25465 & $\begin{array}{l}13555 \\
15753 \\
23896\end{array}$ & $\begin{array}{c}{ }^{1} \mathrm{~A}_{1 \mathrm{~g}} \rightarrow{ }^{1} \mathrm{~A}_{2 \mathrm{~g}} \\
{ }^{1} \mathrm{~A}_{1 \mathrm{~g}} \rightarrow{ }^{1} \mathrm{~B}_{1 \mathrm{~g}} \\
{ }^{1} \mathrm{~A}_{1 \mathrm{~g}} \rightarrow{ }^{1} \mathrm{E}_{\mathrm{g}}\end{array}$ & $\begin{array}{l}\text { Square } \\
\text { planar }\end{array}$ \\
\hline$\left[\mathrm{CuL}^{2}\right]_{2} \cdot 4(\mathrm{OAc})$ & 34367 & 30487 & 25089 & $\begin{array}{l}13052 \\
17848 \\
23157\end{array}$ & $\begin{array}{l}{ }^{2} \mathrm{~B}_{1 \mathrm{~g}} \rightarrow{ }^{2} \mathrm{~A}_{1 \mathrm{~g}} \\
{ }^{2} \mathrm{~B}_{1 \mathrm{~g}} \rightarrow{ }^{2} \mathrm{~B}_{2 \mathrm{~g}} \\
{ }^{2} \mathrm{~B}_{1 \mathrm{~g}} \rightarrow{ }^{2} \mathrm{E}_{\mathrm{g}}\end{array}$ & $\begin{array}{l}\text { Square } \\
\text { planar }\end{array}$ \\
\hline$\left[\mathrm{NiL}^{2}\right]_{2} \cdot 4(\mathrm{OAc})$ & 34496 & 31645 & 24968 & $\begin{array}{l}14454 \\
16956 \\
24763 \\
\end{array}$ & $\begin{aligned}{ }^{1} \mathrm{~A}_{1 \mathrm{~g}} \rightarrow{ }^{1} \mathrm{~A}_{2 \mathrm{~g}} \\
{ }^{1} \mathrm{~A}_{1 \mathrm{~g}} \rightarrow{ }^{1} \mathrm{~B}_{1 \mathrm{~g}} \\
{ }^{1} \mathrm{~A}_{1 \mathrm{~g}} \rightarrow{ }^{1} \mathrm{E}_{\mathrm{g}}\end{aligned}$ & $\begin{array}{l}\text { Square } \\
\text { planar }\end{array}$ \\
\hline
\end{tabular}

The electronic spectra of the binuclear $\mathrm{Cu}(\mathrm{II})$ complexes were recorded in DMSO solution. The copper complexes possesses square planar geometry as evidenced by the appearance of only one band in the electronic spectra at $12,900-13520 \mathrm{~cm}^{-1}$ with two shoulders 15,500-18150, 22450-23,200 cm $\mathrm{cm}^{-1}$. These bands could be assigned to ${ }^{2} \mathrm{~B}_{1 \mathrm{~g}} \rightarrow{ }^{2} \mathrm{~A}_{1 \mathrm{~g}}$, ${ }^{2} \mathrm{~B}_{1 \mathrm{~g}} \rightarrow{ }^{2} \mathrm{~B}_{2 \mathrm{~g}}$, and ${ }^{2} \mathrm{~B}_{1 \mathrm{~g}} \rightarrow{ }^{2} \mathrm{E}_{\mathrm{g}}$ transitions respectively ${ }^{41}$. On the other hand Ni(II) complex showed three absorption bands at 13,500-14500, 15,600-17000 and 23,500-25000 $\mathrm{cm}^{-1}$, which are attributed to ${ }^{1} \mathrm{~A}_{1 \mathrm{~g}} \rightarrow{ }^{1} \mathrm{~A}_{2 \mathrm{~g}},{ }^{1} \mathrm{~A}_{1 \mathrm{~g}} \rightarrow{ }^{1} \mathrm{~B}_{1 \mathrm{~g}}$ and ${ }^{1} \mathrm{~A}_{1 \mathrm{~g}} \rightarrow{ }^{1} \mathrm{E}_{\mathrm{g}}$ transitions ${ }^{42}$.

\section{Electrochemical properties of the complexes}

The electrochemical behavior of the complexes has been examined in DMSO solutions with $0.1 \mathrm{M} \mathrm{NaClO}_{4}$ over the range of +1.2 to $-2 \mathrm{~V}$ using cyclic voltammetry at glassy carbon working electrodes. The electrochemical data of the complexes are summarized in Table 5 and the cyclic voltammogram of some of the complexes are reproduced in the Figures $4 \mathrm{a}-4 \mathrm{~d}$. It is observed that all the binuclear Copper(II) and Nickel(II) complexes show two quasireversible reduction waves in the cathodic potential region. The first reduction potential ranges from -0.91 to $-1.26 \mathrm{~V}$ and the second reduction potential lies in the range of -1.52 to $-1.77 \mathrm{~V}$. Similarly all the complexes show two quasireversible reduction waves in the anodic region, in the range $0.16 \mathrm{~V}$ and $-0.11 \mathrm{~V}$. Controlled potential electrolysis was also carried out and the experiments reports that each process corresponds to one electron transfer process. The stepwise two reduction processes of Copper(II) and Nickel(II) complexes are assigned as follows;

$$
\begin{aligned}
& \mathrm{Cu}^{\mathrm{II}} \mathrm{Cu}^{\mathrm{II}} \rightarrow \mathrm{Cu}^{\mathrm{II}} \mathrm{Cu}^{\mathrm{I}} \rightarrow \mathrm{Cu}^{\mathrm{I}} \mathrm{Cu}^{\mathrm{I}} \\
& \mathrm{Ni}^{\mathrm{II}} \mathrm{Ni}^{\mathrm{II}} \rightarrow \mathrm{Ni}^{\mathrm{II}} \mathrm{Ni}^{\mathrm{I}} \rightarrow \mathrm{Ni}^{\mathrm{I}} \mathrm{Ni}^{\mathrm{I}}
\end{aligned}
$$

Table 5. Electrochemical data of binuclear Schiff base metal complexes

Negative potential

\begin{tabular}{ccccccccc}
\hline Complexes & $\mathrm{E}_{\mathrm{pc}}^{1}(\mathrm{~V})$ & $\mathrm{E}_{\mathrm{pa}}^{1}(\mathrm{~V})$ & $\mathrm{E}^{1}{ }_{1 / 2}(\mathrm{~V})$ & $\Delta \mathrm{E}(\mathrm{mV})$ & $\mathrm{E}_{\mathrm{pc}}^{2}(\mathrm{~V})$ & $\mathrm{E}_{\mathrm{pa}}^{2}(\mathrm{~V})$ & $\mathrm{E}_{1 / 2}^{2}(\mathrm{~V})$ & $\Delta \mathrm{E}(\mathrm{mV})$ \\
\hline$\left[\mathrm{CuL}^{1}\right]_{2} .4(\mathrm{OAc})$ & -1.26 & -0.72 & -0.99 & 540 & -1.77 & -1.45 & -1.61 & 320 \\
{$\left[\mathrm{NiL}^{1}\right]_{2} .4(\mathrm{OAc})$} & -0.91 & - & - & - & -1.25 & -1.01 & -1.13 & 240 \\
{$\left[\mathrm{CuL}^{2}\right]_{2} .4(\mathrm{OAc})$} & -1.09 & -0.7 & -0.89 & 390 & -1.61 & -1.26 & -1.43 & 350 \\
{$\left[\mathrm{NiL}^{2}\right]_{2} .4(\mathrm{OAc})$} & -1.04 & -0.92 & -0.98 & 120 & -1.52 & -1.39 & -1.45 & 130 \\
\hline
\end{tabular}


Positive potential

\begin{tabular}{ccccccccc}
\hline Complexes & $\begin{array}{c}\mathrm{E}_{\mathrm{pc}}^{1} \\
(\mathrm{~V})\end{array}$ & $\begin{array}{c}\mathrm{E}_{\mathrm{pa}}^{1} \\
(\mathrm{~V})\end{array}$ & $\begin{array}{c}\mathrm{E}_{1 / 2}^{1} \\
(\mathrm{~V})\end{array}$ & $\begin{array}{c}\Delta \mathrm{E} \\
(\mathrm{mV})\end{array}$ & $\begin{array}{c}\mathrm{E}_{\mathrm{pc}}^{2} \\
(\mathrm{~V})\end{array}$ & $\begin{array}{c}\mathrm{E}_{\mathrm{pa}}^{2} \\
(\mathrm{~V})\end{array}$ & $\begin{array}{c}\mathrm{E}_{1 / 2}^{2} \\
(\mathrm{~V})\end{array}$ & $\begin{array}{c}\Delta \mathrm{E} \\
(\mathrm{mV})\end{array}$ \\
\hline$\left[\mathrm{CuL}^{1}\right]_{2} \cdot 4(\mathrm{OAc})$ & - & 0.70 & - & - & 0.16 & 0.48 & 0.32 & 320 \\
{$\left[\mathrm{NiL}^{1}\right]_{2} \cdot 4(\mathrm{OAc})$} & - & - & - & - & - & 0.21 & - & - \\
{$\left[\mathrm{CuL}^{2}\right]_{2} \cdot 4(\mathrm{OAc})$} & - & 0.87 & - & - & 0.11 & 0.49 & 0.30 & 380 \\
{$\left[\mathrm{NiL}^{2}\right]_{2} \cdot 4(\mathrm{OAc})$} & - & - & - & - & - & 0.59 & - & - \\
\hline
\end{tabular}

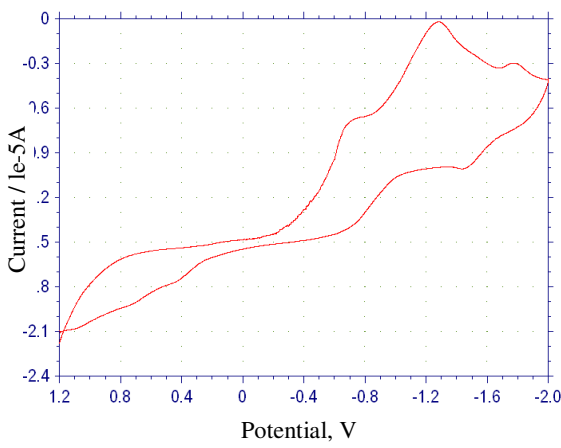

Figure 4a. Cyclic voltammogram of $\left[\mathrm{CuL}^{1}\right] .4(\mathrm{OAc})$

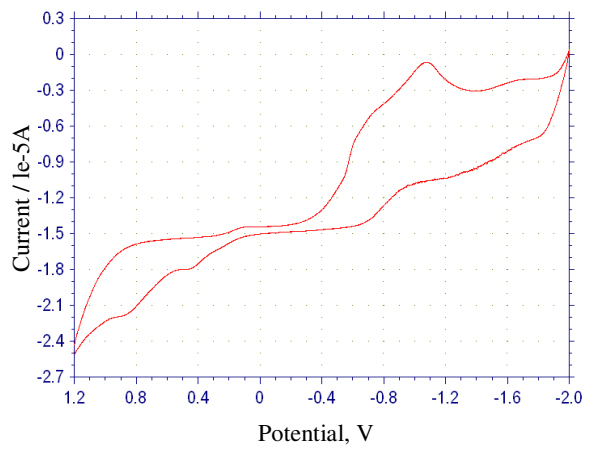

Figure 4c. Cyclic voltammogram of $\left[\mathrm{CuL}^{2}\right] \cdot 4(\mathrm{OAc})$

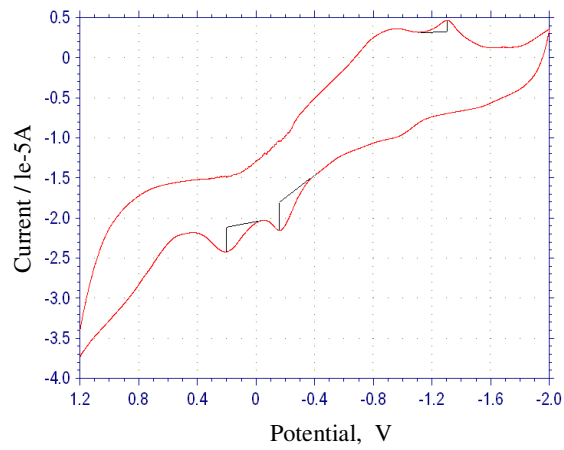

Figure 4b. Cyclic voltammogram of $\left[\mathrm{NiL}^{1}\right] \cdot 4(\mathrm{OAc})$

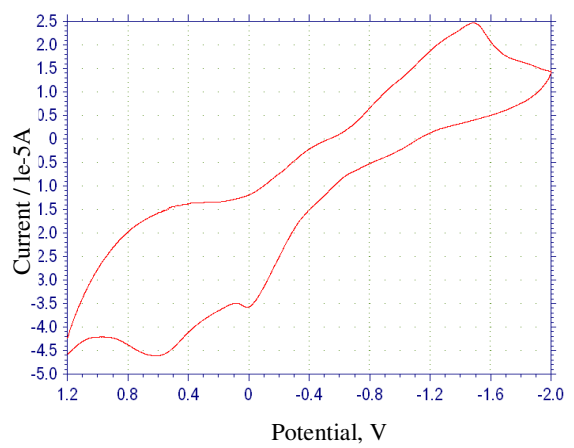

Figure 4d. Cyclic voltammetric studies of $\left[\mathrm{NiL}^{2}\right] .4(\mathrm{OAc})$

These new peaks may be due to a chemical change occurring with the electron transfer. It depends on the structural redeployment in coordination sphere ${ }^{43}$. The complexes with aromatic diimines are reduced at higher potentials. The reason for this may be due to greater planarity and electronic properties that are associated with aromatic rings ${ }^{44}$. Further the presence of electron withdrawing substituent $\left(\mathrm{NO}_{2}\right)$ in the phenyl ring plays an important role in the reduction process ${ }^{45-46}$. These results show that the magnitude of the bimetallic reduction process is subject to vary due to changes caused by the nature of the ligand, geometry and by the presence of the other metal ${ }^{47}$.

All the copper and nickel complexes show two oxidation processes in the range of -0.7 to $-0.92 \mathrm{~V},-1.01$ to $-1.45 \mathrm{~V}$ and 0.70 to $0.87 \mathrm{~V}, 0.21$ to $0.59 \mathrm{~V}$ in cathodic and anodic region. The oxidation process is quasireversible in nature. Controlled potential electrolysis experiment indicates that the two oxidation peaks are associated with stepwise oxidation process at Copper(II) and Nickel(II) center. 


$$
\begin{aligned}
& \mathrm{Cu}^{\mathrm{II}} \mathrm{Cu}^{\mathrm{II}} \rightarrow \mathrm{Cu}^{\mathrm{II}} \mathrm{Cu}^{\mathrm{III}} \rightarrow \mathrm{Cu}^{\mathrm{III}} \mathrm{Cu}^{\mathrm{III}} \\
& \mathrm{Ni}^{\mathrm{II}} \mathrm{Ni}^{\mathrm{II}} \rightarrow \mathrm{Ni}^{\text {II }} \mathrm{Ni}^{\mathrm{III}} \rightarrow \mathrm{Ni}^{\text {III }} \mathrm{Ni}^{\text {III }}
\end{aligned}
$$

The first and second oxidation potential of the complexes of $\mathrm{L}^{1}$ to $\mathrm{L}^{2}$ shifts towards more positive values ${ }^{48}$. This is because for complexes with aromatic diimines, an increase in unsaturation will decrease the electron on the metal through delocalization, on to the ligand and this increases the difficulty to oxidize the metal ion.

\section{Electronic spin resonance spectra}

ESR studies of paramagnetic transition metal(II) complexes give information about the distribution of the unpaired electrons and hence about the nature of the bonding between the metal ion and its ligands. The room temperature ESR spectra of $\left[\mathrm{CuL}^{1}\right]_{2} \cdot 4(\mathrm{OAc})$ and $\left[\mathrm{CuL}^{2}\right]_{2} \cdot 4(\mathrm{OAc})$ were recorded at $\mathrm{X}$ - band frequencies in the solid state. The $\mathrm{g}$ values were calculated using the equation $h v=g \beta H$. The hyperfine splitting of copper nucleus was not observed due to broad signal and $\mathrm{g}_{\text {iso }}$ values of $2.10-2.14$, indicating an antiferromagnetic interaction between the two copper centers. The spectral pattern of the complexes indicating the square-planar geometry around each $\mathrm{Cu}(\mathrm{II})$ center in the binuclear complexes ${ }^{49-50}$. The g values are listed in Table 6.

Table 6. EPR and Magnetic moments (BM) of binuclear Copper(II) complexes.

\begin{tabular}{ccc}
\hline Complexes & EPR, g $_{\text {iso }}$ & Magnetic moment (BM) \\
\hline$\left[\mathrm{CuL}^{1}\right]_{2} \cdot 4(\mathrm{OAc})$ & 2.10 & 1.55 \\
{$\left[\mathrm{CuL}^{2}\right]_{2} \cdot 4(\mathrm{OAc})$} & 2.14 & 1.57 \\
\hline
\end{tabular}

\section{Magnetic moment}

The room temperature magnetic moments of the binuclear Copper(II) complexes are in the 1.55-1.57B.M., which are less than the total spin only values The magnetic moment are listed in Table 6. The lowering of these magnetic moments is due to antiferromagnetic coupling $^{51-53}$. To evaluate the singlet-triplet energy separation $(-2 \mathrm{~J})$, variable temperature magnetic studies for the binuclear copper(II) complexes $\left[\mathrm{CuL}^{1}\right]_{2} \cdot 4(\mathrm{OAc})$ and $\left[\mathrm{CuL}^{2}\right]_{2} \cdot 4(\mathrm{OAc})$ were performed in the temperature range $77-300 \mathrm{~K}$, and the experimental magnetic susceptibility data (Figure 5) were fitted on the Bleaney - Bowers equation ${ }^{54}$.

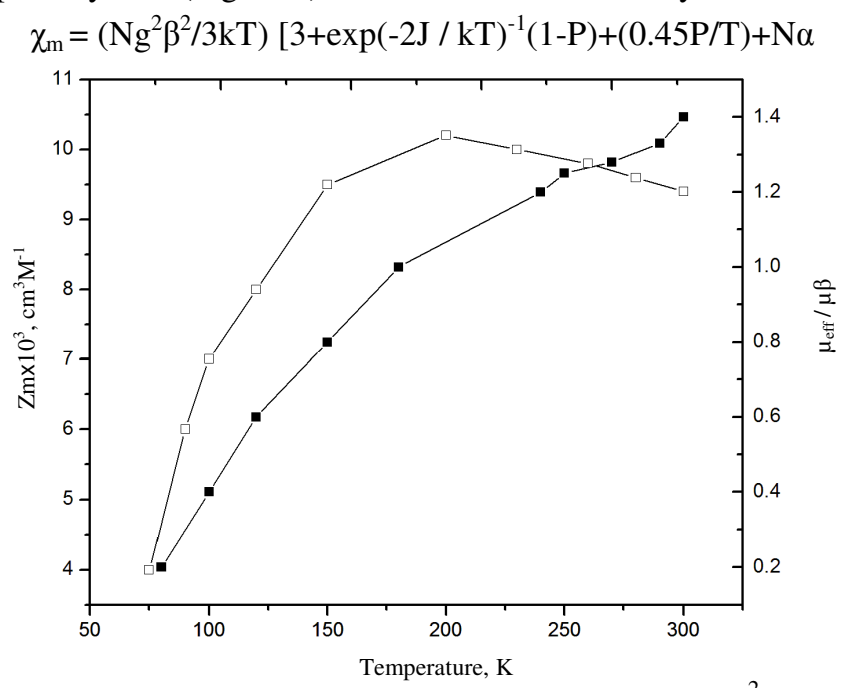

Figure 5. Temperature dependence magnetic properties for $\left[\mathrm{CuL}^{2}\right]_{2} \cdot 4 \mathrm{OAc}$ complex 
Where $\chi_{\mathrm{m}}$ is the paramagnetic susceptibility per metal atom after the correction for diamagmetism, $\mathrm{P}$ is the fraction of monomeric copper(II) impurities, -2J =singlet-triplet energy separation. $\mathrm{N}, \beta, \mathrm{g}$ and $\mathrm{N}_{\alpha}$ are Avogadro number, Boltzmann constant, average gyromagnetic ratio and the temperature independent paramagnetism. In this equation the values of $\mathrm{N}_{\alpha}$ and $\mathrm{g}$ have been fixed as $60 \times 10^{-6} \mathrm{~cm}^{3} \mathrm{M}^{-1}$ and 2.20 respectively.

Since the nature of the donor atoms in all the complexes are the same. The antiferromagnetic exchange interaction (-2J) for the binuclear Copper(II) complexes $\left[\mathrm{CuL}^{1}\right]_{2} \cdot 4(\mathrm{OAc})$ is $198 \mathrm{~cm}^{-1}$ and $\left[\mathrm{CuL}^{2}\right]_{2} \cdot 4(\mathrm{OAc})$ is $226 \mathrm{~cm}^{-1}$. A significantly higher $-2 \mathrm{~J}$ value is observed for the complex of $\mathrm{L}^{2}$ when compared to the complex of $\mathrm{L}^{1}$. The most probable reason for the strong antiferromagnetic exchange interaction in the $\mathrm{L}^{2}$ complex may be greater planarity due to increase chain length of aromatic diamine ${ }^{55}$.

\section{Thermal analysis}

Thermal gravimetric analyses for complexes were obtained to give information concerning the thermal stability of the complex and decide whether the water molecules are in the inner or outer coordination sphere of the central metal ion. The TG-DTA results of the solid complexes, $\left[\mathrm{CuL}^{1}\right]_{2} \cdot 4(\mathrm{OAc})$ and $\left[\mathrm{CuL}^{2}\right]_{2} \cdot 4(\mathrm{OAc})$ are listed in Table 7 . The results show good agreement with the formulae suggested from the analytical data (Table 1)

Table 7. Thermal decomposition of the metal complexes

\begin{tabular}{ccccc}
\hline Complexes & Step & $\begin{array}{c}\text { Temperature } \\
\text { interval, }{ }^{\circ} \mathrm{C}\end{array}$ & $\begin{array}{c}\text { Weight loss } \\
\text { (calculated/ } \\
\text { found), \% }\end{array}$ & $\begin{array}{c}\text { Residue } \\
\text { (calculated/ } \\
\text { found) } \%\end{array}$ \\
\hline$\left[\mathrm{CuL}^{1}\right]_{2} \cdot 4(\mathrm{OAc})$ & 1 & $250-390$ & $37.88 / 36.60$ & $\mathrm{CuO}$ \\
& 2 & $390-575$ & $47.12 / 46.52$ & $(15.00 / 16.88)$ \\
{$\left[\mathrm{CuL}^{2}\right]_{2} \cdot 4(\mathrm{OAc})$} & 1 & $250-420$ & $45.04 / 44.36$ & $\mathrm{CuO}$ \\
& 2 & $420-650$ & $41.72 / 43.12$ & $(13.24 / 12.52)$ \\
\hline
\end{tabular}

The TG and DTG curves of showed the absence of hydrated or coordinated water molecules in the complexes. The $\left[\mathrm{CuL}^{1}\right]_{2} \cdot 4(\mathrm{OAc})$ binuclear complex has two decomposition steps in the range of $250-575^{\circ} \mathrm{C}$. In the first stage the decomposition occurs in the range of 250-390 ${ }^{\circ} \mathrm{C}$, with an estimated mass loss $36.60 \%$ (Calcd. mass loss, 37.88\%). DTG max $_{\max }$ obtained in the range of $310{ }^{\circ} \mathrm{C}$. This was attributed to loss of four acetate groups and aromatic ligand groups. The second stage occurs within the temperature range $390-575{ }^{\circ} \mathrm{C}$, with an estimated mass loss $46.52 \%$ (Calcd.mass loss $47.12 \%$ ). DTG $_{\max }$ obtained in the range of $450{ }^{\circ} \mathrm{C}$. This is reasonably accounted for loss of four 4-nitroaniline groups. Finally the complexes decomposed to $\mathrm{CuO}$ at higher temperatures.

The $\left[\mathrm{CuL}^{2}\right]_{2} \cdot 4(\mathrm{OAc})$ binuclear complex has two decomposition steps in the range of $250-650{ }^{\circ} \mathrm{C}$. The first and second stage of decomposition occurs in the range of $250-420{ }^{\circ} \mathrm{C}$ and $420-650{ }^{\circ} \mathrm{C}$, with a weight loss of $44.36 \%$ (Calcd. $45.04 \%$ ) and $43.12 \%$ (Calcd. $43.72 \%$ ) due to loss of four acetate groups, aromatic ligand group and four 4-nitroaniline groups, confirming the suggested formula of the complexes. $\mathrm{DTG}_{\max }$ obtained in the range of $325{ }^{\circ} \mathrm{C}$ and $510{ }^{\circ} \mathrm{C}$. Final product of the decomposition process is the copper oxide.

\section{Antibacterial activity}

Schiff base ligands and their complexes were screened in vitro in order to evaluate their antibacterial activity against gram positive (Staphylococcus aureus) and gram negative bacteria (Escherichia coli and Bacillus subtilis). The results of the bactericidal screening of 
the synthesized compounds are recorded in Table 8 and shown in Figure 6. All the complexes show superior activity compared to the ligands $\mathrm{L}^{1} \& \mathrm{~L}^{2}$, due to complexes containing aromatic diimines. The complex 3 has the highest antimicrobial activity than other complexes. The order of antimicrobial activity in ligands and complexes are $3>1>4>2>L^{2}>L^{1}$.

Table 8. Antibacterial effects of the ligands and their complexes

\begin{tabular}{cccc}
\hline Compound & Staphylococcus aureus & Escherichia coli & Bacillus subtilis \\
\hline DMSO & - & - & - \\
$\mathrm{L}^{1}$ & + & + & + \\
$\mathrm{L}^{2}$ & ++ & ++ & + \\
{$\left[\mathrm{CuL}^{1}\right]_{2} \cdot 4(\mathrm{OAc})$} & +++ & ++++ & +++ \\
{$\left[\mathrm{NiL}^{1}\right]_{2} .4(\mathrm{OAc})$} & ++ & +++ & +++ \\
{$\left[\mathrm{CuL}^{2}\right]_{2} \cdot 4(\mathrm{OAc})$} & ++++ & ++++ & +++ \\
{$\left[\mathrm{NiL}^{2}\right]_{2} 4(\mathrm{OAc})$} & ++ & +++ & +++ \\
\hline
\end{tabular}

Inhibition zone diameter in mm (\% inhibition): (-) 0, (+) 7-10 (35-45\%); (++) 10-15 (45-73\%); (+++) 15-19 (73-86); (++++) 19-22(86-100\%). Percent inhibition values are relative to inhibition zone (22mm) with $100 \%$ inhibition

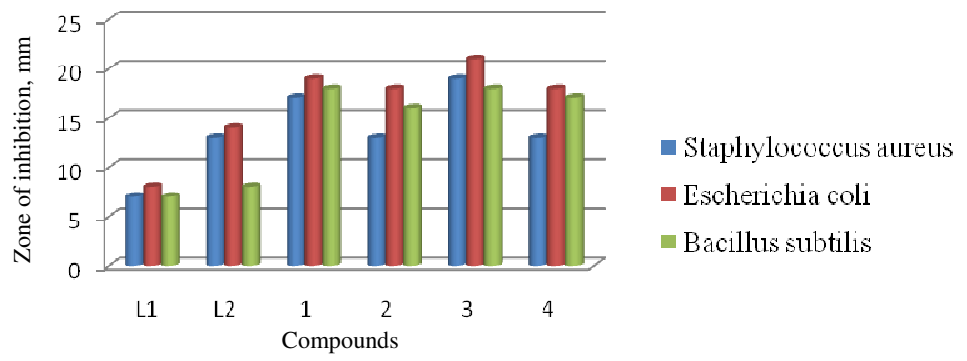

Figure 6. Antimicrobial activity of binuclear ligands and its metal complexes, $\mathrm{L}^{1}\left(\mathrm{C}_{20} \mathrm{H}_{16} \mathrm{~N}_{6} \mathrm{O}_{4}\right)$, $\mathrm{L}^{2}\left(\mathrm{C}_{26} \mathrm{H}_{20} \mathrm{~N}_{6} \mathrm{O}_{4}\right),(1)\left[\mathrm{CuL}^{1}\right]_{2} \cdot 4(\mathrm{OAc}),(2)\left[\mathrm{NiL}^{1}\right]_{2} \cdot 4(\mathrm{OAc}),(3)\left[\mathrm{CuL}^{2}\right]_{2} \cdot 4(\mathrm{OAc}),(4)\left[\mathrm{NiL}^{2}\right]_{2} \cdot 4(\mathrm{OAc})$ [Y axis - zone of inhibition ( $\mathrm{mm})$ ]

The observed higher antimicrobial activities of the complexes can be explained on the basis of Tweedy's theory ${ }^{56}$. Chelation considerably reduces the polarity of the central ion mainly because of the partial sharing of its positive charge with the donor groups and possible $\pi$-electron delocalization within the whole chelate ring. This chelation enhances the lipophilic nature of the central atom which favours its permeation through the lipid layer of the cell membrane. Higher activity observed against the gram negative bacteria Escherichia coli can be explained by considering the effect on lipo-polysaccharide (LPS), a major component of the surface of gram negative bacteria ${ }^{57}$. LPS is an important entity in determining the outer membrane barrier function and the virulence of Gram negative pathogens. The Schiff base can penetrate the bacterial cell membrane by coordination of metal ion through nitrogen donor atom to LPS which leads to the damage of outer cell membrane and consequently inhibits growth of the bacteria. Though there is sufficient increase in the bacterial activity of complexes as compared to the free ligands.

\section{Conclusion}

New binucleating Schiff base ligands $\mathrm{L}^{1}, \mathrm{~L}^{2}$ and its copper(II) and nickel(II) complexes were synthesized and characterized. The structural properties of ligands and complexes were proposed based on elemental analysis and spectral studies. The ligands $\mathrm{L}^{1}, \mathrm{~L}^{2}$ acts as bidentate ligands through the azomethine nitrogen and primary amine groups, forming strong 
complexes with the metal centre $\mathrm{Ni}(\mathrm{II})$ and $\mathrm{Cu}(\mathrm{II})$. According to electronic spectra the proposed stereochemistry is square planar for both complexes. Conformation regarding the stoichiometry, nature and overall geometry around the metal ion was further deduced from the EPR, magnetic moment values and conductivity measurements. Thermal decomposition of complexes gave the composition of complexes and also the intervals of thermal stability. The ligand $\mathrm{L}^{1}, \mathrm{~L}^{2}$ and its $\mathrm{Cu}(\mathrm{II})$ and $\mathrm{Ni}(\mathrm{II})$ complexes were tested for antimicrobial activity against some pathogens. All the complexes were found to be more active than ligands and streptomycin (standard). $\left[\mathrm{CuL}^{2}\right]_{2} \cdot 4(\mathrm{OAc})$ complex showed the best antimicrobial activity against Gram positive and Gram negative bacteria.

\section{Acknowledgement}

We are grateful to the University Grant Commission (UGC), New Delhi for financial support in the form of Major Research Project [MRP- F.No 37-299/2009 (SR)] of this work.

\section{References}

1. Akine S, Sunaga S, Taniguchi T, Miyazaki H and Nabeshima T, Inorg Chem., 2007, 46, 2959-2961.

2. Anacona J R, Bastardo E and Camus J, Trans Met Chem., 1999, 24(4), 478-480.

3. Keskioglu E, Balaban Gunduzalp A, Cete S, Hamurcu F and Erk B, Spectrochimica Acta A: Molecular Biomolecular Spectroscopy, 2008, 70(3), 634-640.

4. Taggi A E, Hafez A M, Wack H, Young B, Ferraris D and Lectka T, J Am Chem Soc., 2002, 124(23), 6626-6635.

5. Venturini A and Gonzalez J, J Org Chem., 2002, 67(25), 9089-9092.

6. Delpiccolo C M L and Mata E G, Tetrahedron Asymmetry, 2002, 13(9), 905-910.

7. Rosu T, Pahontu E, Maxim C, Georgescu R, Stanica N, Almajan G L and Gulea A, Polyhedron, 2010, 29(2), 757-766.

8. Zhang H, Zhang Y and Li C, J Catal., 2006, 238(2), 369-381.

9. Wen J, Zhao J, Wang X, Dong J and You T, J Mol Catal., 2006, 245(1-2), 242-247.

10. Lozan V, Loose C, Kortus J and Kersting B, Coord Chem Rev., 2009, 253(19-20), 2244-2260.

11. Sallam S A, Trans Met Chem., 2006, 31(1), 46-55.

12. Costamagna J, Vargas J, Latorre R, Alvarado A and Mena G, Coord Chem Rev., 1992, 119, 67-88.

13. Bindlish J M, Bhatia S C and Jain P C, Indian J Chem., 1975, 13, 81-82.

14. Maverick A W, Buckingham S C, Yao Q, Bradbury J R and Stanley G G, J Am Chem Soc., 1986, 108(23), 7430-7431.

15. Caulder D L and Raymond K N, Angew Chem Int Ed Engl., 1997, 36(13-14), 1440-1442.

16. Su Z, Chen S S, Fan J, Chen M S, Zhao Y and Sun W Y, Cryst Growth Des., 2010, 10(8), 3675-3684.

17. Vigato P A, Tamburini S and Fenton D E, Coord Chem Rev., 1990, 106, 25-170.

18. Sorenson J R, J Chem Br., 1984, 16, 1110.

19. Crouch R K, Kensler T W, Oberlay L W, Sorenson J R G, Karlin K D and Zubieta J, Biol Inorg Copper Chem.; Adenine: New York, 1986, 139.

20. Khanmohammadi H, Amani S, Lang H and Rueffer T, Inorg Chim Acta, 2007, 360(2), 579-587.

21. Lecomte C, Dahaoui-Gindrey V, Chollet H, Gros C, Mishra A K, Barbette F, Pullumbi P and Guilard R, Inorg Chem., 1997, 36(18), 3827-3838. 
22. Liu W, Jiao T, Li Y, Liu Q, Tan M, Wang H and Wang L, J Am Chem Soc., 2004, 126(8), 2280-2281.

23. Corriu R J P, Embert F, Guari Y, Reye C and Guilard R, Chem Eur J., 2002, 8(24), $5732-5741$.

24. Gorden A J and Ford R A, The Chemist's Companion, A Handbook of Practical Data, Techniques and References; John Wiley \& Sons, 1972; ISBN: 978-0-471-31590-2

25. Dave R H and Hosangadi B D, Tetrahedron, 1999, 55(37), 11295-11308.

26. Jeffrey G H, Basset J, Mandham J and Denny R J, Vogel's Quantitative chemical Analysis; $5^{\text {th }}$ Edition., Longmand science and Tech, Sussex; UK, 1989, 447.

27. Gakias S, Rix C, Fowless A and Hobday M, Inorganica Chimica Acta, 2006, 359(7), 2291-2295.

28. Collins C H, Lyne P M and Grange J M, Microbiological Methods, $3^{\text {rd }}$ Edition, Butterworth, 1989, 410.

29. Geary W J, Coord Chem Rev., 1971, 7, 81-122.

30. Refat M S, El-Deen I M, Ibrahim H K and El-Ghool S, Spectrochemica Acta part A: Molecular Biomolecular Spectroscopy, 2006, 65(5), 1208-1220.

31. Socrates G, Infrared and Raman Characteristic Group Frequencies : Tables and Charts, John Wiley \& Sons Inc.; ISBN 13: 9780470093078

32. Das G, Shukala R, Mandal S, Singh R, Bharadwaj P K, Hall J V and Whitemine K H, Inorg Chem., 1997, 36(3), 323-329.

33. Silverstein R M and Bassler G C, Spectroscopic Identification of Organic Compounds, John Wiley \& Sons, New York, 1991.

34. Fraser C, Ostrander R, Rheingold A L, White C and Bosnich B, Inorg Chem., 1994, 33, 324.

35. Prasad R N, Mathur M and Upadhayay A, J Indian Chem Soc., 2007, 84, 1202-1204.

36. Costamagna J, Ferraudi G, Villagran M and Wolcan E, J Chem Soc Dalton Trans., 2000, 2631- 2637.

37. Nakamoto K, Infrared and Raman Spectra of Inorganic and Coordination Compounds; Wiley Interscience publication, 1978.

38. Holman T R, Hendrich M P and Jr Que L, Inorg Chem., 1992, 31, 937-939.

39. Manonmani J, Kandaswamy M, Narayanan V, Thirumurugan R, Shanmuga Sundura Raj S, Shanmugam G, Ponnuswamy M N and Fun H K, Polyhedran, 2001, 20(26-27), 3039-3048.

40. Bjerrum J, Ballhausen C J and Jorgensen C K, Acta Chem Scand., 1954, 8, 1275-1289.

41. Emara A A A, Synth React Inorg Met-Org Chem., 1999, 29, 87.

42. Emara A A A and Adly O M I, Trans Met Chem., 2007, 32(7), 889-901.

43. Tumer M, Ekinci D, Tumer F and Bulut A, Spectrochemica Acta Part A: Molecular Biomolecular Spectroscopy, 2007, 67, 916-929.

44. Thirumavalavan M, Akilan P and Kandaswamy M, Supramolecular Chem., 2004, 16(2), 137-146.

45. Alexander V, Chem Rev., 1995, 95(2), 273-342.

46. Mahalakshmy R, Venkatesan R, Sambasiva Rao P S, Kannappan R and Rajendiran T M, Trans Met Chem., 2004, 29, 623.

47. Belle C, Beguin C, Luneau G I, Hamman S and Philouze C, Pierre J L, Thomas F, Torelli S, Saint-Aman E and Bonin M, Inorg Chem., 2002, 41(3), 479-491.

48. Gao E Q, Bu W M, Yang G M, Liao D Z, Jiang Z H, Yan S P and Wang G L, J Chem Soc Dalton Trans., 2000, 1431-1436.

49. Greenwood N N and Earnshaw A, Chemistry of the Element; Pergamon Press, New York, 1984. 
50. Harris G, Theor Chim Acta, 1966, 5, 379.

51. Lubben M, Hage R, Meetsma A, Byma K and Fermga B L, Inorg Chem., 1995, 34(8), 2217-2274.

52. Banzakri A, Dubourdeaux P, Latour J M, Laugier J, Rey P and Jean Laugier, $J$ Chem Soc Dalton Trans., 1991, 3359.

53. Thompson L K, Mandal S K, Tandon S S, Bridson J N and Park M K, Inorg Chem., 1996, 35(11), 3117-3125.

54. Bleany B and Bowers K D, Porc Royal Soc London Ser A., 1952, 214, 415.

55. Sreedaran S, Shanmuga Bharathi K, Kalilur Rahiman A, Jagadish L, Kaviyarasan V and Narayanan V, Polyhedron, 2008, 27(13), 2931-2938.

56. Tweedy B G, Phytopathology, 1964, 55, 910-914.

57. Islam M S and Farooq M A, J Bio Sci., 2002, 2, 797-800. 